\title{
PRINSIP DAN SYARAT PENJATUHAN HUKUMAN BAGI ANAK BERKONFLIK HUKUM
}

\author{
Rasdianah \\ Universitas Ichsan Gorontalo \\ Email: rasdianah.diana61@gmail.com
}

\begin{abstract}
The principle of imposing the punishment of a child of the perpetrator of a crime so that there is a reason for the criminal sanction to qualify for forgiveness, also the enactment of two forms of punishment (acts and criminal) for a child in conflict law is a further embodiment of the three punishment principles recognized in UUSPPA, namely the principle of criminal liability, the best interes of the child and ultimum remidium principle. The three principles of punishment also form the foundation of UUSPPA formers so that there are two conditions of punishment for children in conflict law, namely the absolute punishment requirements and relative condemnation requirements.

Keywords: Principle of Punishment, Punishment Requirement, Child Conflict Law
\end{abstract}

\begin{abstract}
Abstrak
Prinsip penjatuhan hukuman bagi anak pelaku tindak pidana sehingga terdapat alasan penghapus pidana berkualifikasi alasan pemaaf, juga diberlakukannya dua bentuk hukuman (tindakan dan pidana) bagi anak berkonflik hukum merupakan perwujudan lebih lanjut dari tiga prinsip penghukuman yang diakui dalam UUSPPA, yaitu prinsip pertanggungjawaban pidana, prinsip the best interes of the child dan prinsip ultimum remidium. Ketiga prinsip penghukuman tersebut juga menjadi landasan dari pembentuk UUSPPA sehingga diberlakukan dua syarat penghukuman bagi anak berkonflik hukum, yaitu syarat penghukuman absolut dan syarat penghukuman relatif.
\end{abstract}

Kata Kunci: Prinsip Penjatuhan Hukuman, Syarat Penjatuhan Hukuman, Anak Berkonflik Hukum 


\section{PENDAHULUAN}

$\mathrm{K}$ asus anak berkonflik hukum di negeri ini tergolong tinggi. Berdasarkan tabulasi bank data kasus perlindungan anak yang dimiliki KPAI, dari tahun 2011 hingga 2016 sebanyak 7.132 ABH. ${ }^{1}$ Tak terkecuali di kota Makassar, kasus anak berkonflik hukum juga tergolong tinggi dari tahun ke tahun. Mulai dari tahun 2012 sampai dengan tahun 2016 angka kejahatan yang dilakukan oleh anak tidak pernah absen setiap tahunnya.

Total jumlah kejahatan di Kota Makassar yang telah divonis di Pengadilan Negeri Makassar dari tahun 2012 sampai dengan tahun 2016 yaitu: kasus penganiayaan sudah berjumlah 54 kasus, kasus pembunuhan sudah berjumlah 20 kasus, kasus narkotika sudah berjumlah 117 kasus, kasus pencurian sudah berjumlah 2893 kasus, dan kasus kepemilikan senjata tajam sudah berjumlah 206 kasus. $^{2}$

Tingginya angka kejahatan yang dilakukan oleh anak, selanjutnya disebut anak berkonflik hukum (ABH) berdasarkan Undang-undang Nomor 11 Tahun 2012 tentang Sistem Peradilan Pidana Anak (disingkat UUSPPA), sehingga menjadi patut untuk kembali membahas hak perlakuan khusus bagi anak berkonflik hukum ketika dikenakan hukuman berdasarkan vonis pengadilan.

Batasan usia anak berkonflik hukum telah dipertegas berdasarkan Pasal 1 angka 3 UUSPPA, yaitu dari usia 12 tahun sd. Usia 18 tahun saja yang dapat diproses secara pidana, mulai dari penyelidikan hingga jatuhnya hukuman melalui putusan pengadilan.

Adapun yang menjadi dasar perubahan batasan usia anak berkonflik hukum tersebut, yaitu sebagai penyesuaian dari Putusan MK Nomor 1/PUUVIII/2010 yang dalam ratio decidendi-nya menyatakan:

"Bahwa dengan perubahan batasan usia minimal pertanggungjawaban hukum bagi anak adalah 12 tahun, mahkamah berpendapat hal tersebut membawa implikasi hukum terhadap batas umur minimum (minimum age floor) bagi anak nakal (deliquent child) sebagaimana yang ditentukan Pasal 1 ayat 1 UU Pengadilan Anak yang menyatakan "anak adalah orang yang dalam perkara anak nakal telah mencapai umur 8 (delapan) tahun tetapi belum mencapai umur 18 (delapan belas) tahun dan belum pernah kawin," Oleh karena itu mahkamah berpendapat bahwa meskipun pasal a quo tidak dimintakan pengujian oleh para pemohon, namun pasal a quo merupakan jiwa atu roh dari undang-undang pengadilan anak,

\footnotetext{
${ }^{1}$ Sumber: kpai.go.id

${ }^{2}$ Sumber: Pengadilan Negeri Makassar.
} 
terutama Pasal 4 ayat 1 dan Pasal 5 ayat 1 UU Pengadilan Anak, sehingga batas umur minimum juga harus disesuaikan agar tidak bertentangan dengan UUD 1945, yakni 12 (dua belas) tahun."

Konsekuensi lebih lanjut atas batas usia anak berkonflik hukum, ialah terdapat anak sebagai pelaku tindak pidana yang tidak dapat diproses secara pidana, di saat usianya masih di bawah 12 tahun. Hal ini dalam hukum pidana terkait dengan prinsip pertanggungjawaban pidana dalam ruang lingkup alasan penghapus pidana.

Antara model pertangungjawaban pidana dan penghukuman bagi anak pelaku tindak pidana yang terdapat dalam UUSPPA, hingga saat ini masih banyak yang menimbulkan reaksi penolakan dari masyarakat. Disaat ada anak yang melakukan tindak pidana, jika hanya dikenakan hukuman berupa tindakan oleh majelis hakim pengadilan, putusan itu kemudian dianggap tidak memenuhi rasa keadilan masyarakat. Atau dengan kata lain dianggap tidak sesuai dengan norma hukum primer, ${ }^{3}$ sebagai kaidah yang sesuai dengan jiwa suatu bangsa (volkgeist). ${ }^{4}$

Bertitik tolak dari situasi tersebut, sehingga menjadi penting untuk mengemukakan poin yang menjadi dasar atau basis argumentasi sehingga anak sebagai pelaku tindak pidana ketika dikenakan hukuman terdapat perbedaan dengan pelaku tindak pidana yang sudah berusia dewasa.

Poin yang penulis maksudkan, yaitu prinsip hukum yang menjadi dasar falsafati dan dasar teoritis sehingga anak pelaku tindak pidana dibebaskan dari pertanggungjawaban pidana, atau anak pelaku tindak pidana dibebani pertanggunggjawaban pidana dengan hukuman tindakan/hukuman pidana.

Khusus pertanggungjawaban pidana bagi anak pelaku tindak pidana dalam kualifikasi tidak dibebani pertanggungjawaban, hingga saat ini belum terdapat lietatur yang menjelaskan secara komprehensif teori-teori yang mendasarinya sehingga anak yang masih di bawah umur 12 tahun dihapuskan pidananya, karena tidak memiliki kemampuan bertanggung jawab.

Dalam konteks itulah, yang didasarkan UUSPPA sehingga memunculkan postulat hukum bahwa tidak semua anak pelaku tindak pidana adalah anak berkonflik hukum. Bagi anak pelaku tindak pidana yang tidak terkualifikasi sebagai anak berkonflik hukum, tidak dapat dibebani pertanggungjawaban pidana. Dan dalam hal karena tidak memiliki kemampauan bertanggung jawab itu, maka

\footnotetext{
${ }^{3}$ Hart, 2013, Konsep Hukum, Bandung: Nusa Media, Hlm. 172.

${ }^{4}$ Kutipan pendapat F.C. von Savigny oleh Achmad Ali, 2002, Menguak Tabir Hukum, Jakarta: Toko Gunung Agung, Hlm. 274.
} 
anak pelaku tindak pidana yang berusia di bawah 12 tahun, memenuhi kualifikasi alasan penghapus pidana berupa alasan pemaaf.

Perbedaan yang mendasar dari segi kemampuan bertanggung jawab anatara anak dan orang dewasa ketika melakukan tindak pidana, juga diilhami oleh prinsip penghukuman yang harus mengutamakan kepentingan terbaik bagi anak (the best interest of the child) dan mengenakan pidana penjara sebagai upaya terakhir (ultimum remidium).

Dengan menelaah prinsip penjatuhan hukuman bagi anak pelaku tindak pidana, tentunya memiliki hubungan pula dengan syarat penjatuhan hukuman yang diberlakukan bagi anak berkonflik hukum dengan harus berdasarkan pada tiga prinsip hukum tersebut di atas, yaitu prinsip pertanggungjawaban pidana, prinsip pengutamaan kepentingan terbaik bagi anak, dan prinsip ultimum remidium. Adapun yang menjadi fokus pembahasan dari penelitian ini, ialah prinsip dan syarat penjatuhan hukuman bagi anak berkonflik hukum.

\section{PEMBAHASAN}

\section{A. Prinsip Penjatuhan Hukuman Bagi Anak Berkonflik Hukum}

UUSPPA mencantumkan 10 (sepuluh) bagian asas-asas hukum yang terkait dengan penegakan hukum bagi anak berkonflik hukum. Sedangkan dalam tulisan ini hanya diperkenalkan tiga asas-asas hukum atau prinsip hukum yang sesuai dengan syarat penjatuhan hukuman bagi anak berkonflik hukum.

Ketiga prinsip hukum yang akan dikemukakan berikut ini memiliki hubungan atau keterkaitan satu sama lainnya dalam hal menentukan hukuman yang memenuhi tujuan keadilan dan kemanfaatan bagi anak berkonflik hukum.

\section{Prinsip Pertanggungjawaban Pidana}

Mengenai anak yang melakukan tindak pidana, hingga saat ini belum ada penjelasan secara teoritik dalam literatur yang menguraikannya sebagai salah satu tindak pidana yang dapat dibebaskan dari pertanggungjawaban pidana. Atau apa yang lazimnya, dikenal dengan istilah alasan penghapus pidana.

Pasal 45 Kitab Undang-undang Hukum Pidana pada hakikatnya tidak mengenal alasan penghapus pidana bagi anak yang melakukan tindak pidana. Hal itu dapat dicermati berdasarkan bunyi ketentuannya sebagai berikut:

“...Jika seorang yang belum dewasa dituntut karena perbuatan yang dikerjakannya ketika umurnya belum enam belas tahun, hakim boleh memerintahkan, supaya sitersalah itu dikembalikan kepada orang tuanya, walinya atau pemeliharanya, dengan tidak dikenakan suatu hukuman...." 
Dengan memperhatikan secara cermat ketentuan di atas, frasa dari "dengan tidak dikenakan suatu hukuman" ternyata yang dimaksudkan adalah tidak dikenakan bentuk hukuman pokok, maupun hukuman tambahan. Akan tetapi hukuman yang dijatuhkan adalah hukuman berupa tindakan (matregel). ${ }^{5}$ Sebuah kekeliruan sebenarnya Pasal 10 KUHP yang tidak mengakomodasi jenis hukuman berupa tindakan, lalu dalam Pasal 45 KUHP dikenal hukuman tindakan bagi anak pelaku tindak pidana, berupa: pengembalian ke orang tua, atau diserahkan kepada pemerintah. Selain itu, KUHP juga belum mengatur batasan usia minimum bagi anak yang dapat diajukan ke persidangan. ${ }^{6}$

Hal yang berbeda kemudian dengan Pasal 1 angka 2 UUSPPA yang telah mengatur ketentuan penghapusan pidana bagi anak pelaku tindak pidana. Hal itu dapat dicermati berdasarkan bunyi ketentuannya sebagai berikut:

"Anak yang berkonflik dengan hukum yang selanjutnya disebut anak adalah anak yang telah berumur 12 (dua belas) tahun, tetapi belum berumur 18 tahun yang diduga melakukan tindak pidana."

Apa makna yang terkandung dari ketentuan di atas? Batasan umur bagi yaitu 12 tahun sd. 18 tahun, bagi anak yang melakukan tindak pidana dengan umur di bawah 12 tahun, misalnya 5 tahun, 6, tahun, 7 tahun, dst, menegasikan anak tersebut bukan dalam kualifikasi anak berkonflik hukum. Itu artinya, kalau ada anak yang melakukan tindak pidana, di bawah batasan umur 12 tahun, perbuatan pidananya menjadi terhapus, dan memenuhi syarat inkompetensi sistem peradilan pidana (incompetence to stand trial). ${ }^{7}$

Dengan masih berdasarkan ketentuan di atas, maka dapat dikatakan pula kalau UUSPPA pada intinya menegaskan bahwa "tidak semua anak pelaku tindak pidana adalah anak berkonflik hukum." Kemudian, jika dihubungkan dengan adagium "tidak semua pelaku tindak pidana dapat bertanggung jawab secara pidana," karena terdapat alasan penghapus pidana, maka "tidak semua anak pelaku tindak pidana dapat bertanggung jawab secara pidana.” Yang mana anak pelaku tindak pidana tidak dapat bertanggung jawab secara pidana? Yaitu yang berumur di bawah 12 tahun.

Dalam konteks demikian, bahwa dikenalnya alasan penghapus pidana bagi anak pelaku tindak pidana prasyarat di bawah umur 12 tahun, maka isu pokoknya, yaitu: Pertama, apa dasar filsufis atau teori hukum yang dapat mem-back up

${ }^{5}$ E. Utrecht, 1965, Hukum Pidana II, Djakarta: Pustaka Tinta Mas, Hlm. 342.

${ }^{6}$ Bunadi Hidayat, 2014, Pemidanaan Anak di Bawah Umur, Bandung: Alumni, Hlm. 58.

${ }^{7}$ Mark Conztanzo, 2006, Aplikasi Psikologi dalam Sistem Hukum, Jakarta: Pustaka Pelajar, HIm 153. 
sehingga anak pelaku tindak pidana yang berumur di bawah 12 tahun tidak dapat di pidana? Kedua, jenis alasan penghapus pidana apakah yang sesuai dengan anak pelaku tindak pidana yang berumur di bawah 12 tahun, sebagaimana yang dianut dalam prinsip pertanggungjawaban pidana saat ini?

Untuk mengukur kemampuan bertanggungjawab pidana dari si pembuat pidana, van Hammel menguraikannya, yang terdiri atas 3 bagian sebagai berikut: ${ }^{8}$

a. Матри memahami secara sungguh-sungguh akibat dari perbuatannya;

b. Mampu untuk menginsyafi bahwa perbuatan itu bertentangan dengan ketertiban masyarakat;

c. Mampu menentukan kehendak untuk berbuat.

Tidak ada artinya kemudian, syarat kemampuan bertanggung jawab sebagaimana yang dikemukakan oleh van Hammel tersebut di atas, kalau tidak dihubungkan dengan keadaan psikologis bagi anak pelaku tindak pidana berdasarkan batasan usianya, sehingga dapat dikategorikan bertanggung jawab atau tidak bertanggung jawab atas perbuatan pidananya.

Salah satu penulis hukum pidana dalam perspektif hukum Islam yang monumental, yaitu A. Hanafi dapat menjadi rujukan perihal hubungan antara usia anak dengan kemampuannya bertanggung jawab secara pidana. Beliau mengemukakan: ${ }^{9}$

"Menurut hasil penyelidikan para Fuqaha, untuk mengukur kemampuan bertanggung jawab bagi anak sebagai pelaku tindak pidana berdasarkan usianya, dikelompokkan dalam tiga bagian, yaitu:

a. Masa tidak adanya kemampuan berpikir;

b. Masa kemampuan berpikir lemah;

c. Masa kemampuan berpikir penuh."

Kendatipun apa yang dikemukakan oleh A. Hanafi mengenai batasan umur bagi anak pelaku tindak pidana, berbeda antara hukum pidana Islam dengan hukum pidana positif kita, yaitu hukum pidana Islam: 7 tahun ke bawah, hukum pidana positif (UUSPPA): di bawah 12 tahun dalam hal anak tidak dapat dipidana. Akan tetapi dengan adanya kualifikasi masa tidak adanya kemampuan berpikir, maka hal demikian sejalan dengan syarat tidak mampunya seorang untuk dikatakan bertanggung jawab pidana sebagaimana yang dikemukakan oleh van Hammel. Seorang anak tidak memiliki kemampuan berpikir maka sudah pasti

${ }^{8}$ G. A. Van Hammel,1913, Inleiding Tot de Studie Van Het Nederlansche strafrecht, De Erven F. Bohn Haarlen \& Gebr. Belinfante's-Gravenhage: Derde Druk, Hlm. 387. 400.

9 A. Hanafi, 1976, Asas-asas Hukum Pidana Islam, Jakarta: Bulan Bintang, Hlm. 398 - 
tidak mampu memahami secara sungguh-sungguh akibat dari perbuatannya, tidak mampu untuk menginsyafi bahwa perbuatan itu bertentangan dengan ketertiban masyarakat, dan tidak mampu menentukan kehendak untuk berbuat.

Terdapat hal menarik dari pengklasifikasian batasan usia anak sehingga dapat bertanggung jawab secara pidana sebagaimana yang dikemukakan oleh A. Hanafi di atas. Jika UUSPPA anak menentukan bahwa bagi anak pelaku tindak pidana, yang berumur di bawah 14 tahun, hanya dapat dikenakan hukuman tindakan, maka dasar filsufis atau teori yang menjadi dasar pijakannya, yaitu dapatnya dijatuhkan hukuman tindakan bagi anak yang berumur di bawah 14 tahun, karena usia anak masih dalam kategori masa berpikir lemah. Demikian halnya juga berlaku dengan dapatnya dijatuhkan pidana bagi anak yang berumur 14 tahun sd 18 tahun, jelas berpijak pada basis teori bahwa usia anak sudah dalam kategori masa berpikir penuh.

Sehubungan dengan jenis alasan penghapus pidana apakah yang sesuai dengan anak pelaku tindak pidana yang berumur di bawah 12 tahun, sebagaimana yang dianut dalam prinsip pertanggungjawaban pidana saat ini. Dengan berdasarkan uraian di atas, maka dapat tergambarkan pula bahwa jenis alasan penghapus pidana bagi anak pelaku tindak pidana yang berumur di bawah 12 tahun, yaitu alasan penghapus pidana berupa alasan pemaaf.

Fletcher mengemukakan bahwa dalam alasan pemaaf, perbuatan tersebut salah, akan tetapi masih dipertanyakan, apakah pelaku dapat dipertanggung jawabkan atau tidak. ${ }^{10}$ Dalam hubungan itu, Eddy O.S. Hiariej mengemukakan pula bahwa alasan pemaaf mempertanyakan apakah pelakunya dapat dipertanggungjawabkan atas perbuatan yang salah, yang dalam hal ini alasan pemaaf menghapuskan elemen dapat dicelanya pelaku. ${ }^{11}$

Alasan penghapus pidana berupa alasan pemaaf terikat oleh teori hukuman yang tidak perlu (theory of pintless punishment). Tidak ada manfaatnya menjatuhkan pidana kepada orang yang tidak memiliki kemampuan berpikir atau kehendak yang terinsafi dalam berbuat salah.

Prinsip pertanggungjawaban pidana yang mengatakan bahwa orang yang melakukan tindak kejahatan tanpa kesadaran penuh seharusnya tidak bertanggung jawab atas tindak kejahatannya itu, maka kepada anak pelaku tindak pidana yang di bawah umur 12 tahun, adalah sebagai pelaku yang tidak dapat dicela, kepada

\footnotetext{
HIm. 813.

11 Eddy O.S Hiariej, 2016, Prinsip-prinsip Hukum Pidana, Yogyakarta: Cahaya Atma Pustaka, Hlm 253.
}

${ }^{10}$ George P. Fletcher, 1998, Basic Concepts of Criminal Law, Cambridge: University Press, 
dirinya sebagai pembuat pidana yang dimaafkan dengan dasar tidak adanya kemampuan berpikir.

Demikian pula dengan prinsip pertanggungjawaban pidana, bahwa kepada si pelaku tindak pidana yang dapat membuat pilihan yang diketahuinya sebagai perbuatan dosa di mata Tuhan dan sebagai tindak pidana di mata negara, maka kepada anak pelaku tindak pidana yang di bawah umur 12 tahun, dianggap sebagai orang yang belum mengetahui perbuatan pidananya sebagai dosa di mata Tuhan dan sebagai tindak pidana di mata negara. Anak pelaku tindak pidana dalam kategori demikian, selain tidak memiliki kemampuan berpikir (iradah), juga belum terikat prinsip indeterminasi, ${ }^{12}$ yaitu sebagai kebebasan untuk memilih dalam berbuat atau bertindak secara benar atau salah (ikhtiar).

\section{Prinsip Pengutamaan Kepentingan Terbaik Bagi Anak}

The best interes of the child principle atau yang lazimnya dikenal dengan prinsip kepentingan terbaik bagi anak juga dianut dalam penjatuhan hukuman bagi anak pelaku tindak pidana sebagaimana yang diatur dalam UUSPPA.

Sebelum prinsip pengutamaan kepentingan terbaik bagi anak di atur dalam UUSPPA, telah diatur dalam Pasal 1 Konvensi Hak Anak yang menegaskan:

"Dalam semua tindakan mengenai anak, yang dilakukan oleh lembagalembaga kesejahteraan sosial negara atau swasta, pengadilan hukum, penguasa administratif atau badan legislatif, kepentingan-kepentingan terbaik anak harus merupakan pertimbangan utama."

Kemudian, dalam Pasal 2 huruf d UUSPPA, ditegaskan pula:

"Sistem peradilan pidana anak dilaksanakan berdasarkan asas kepentingan terbaik bagi anak.”

Dalam Pasal 2 huruf b UU Perlindungan Anak ditegaskan pula:

"Penyelenggaraan perlindungan anak berasaskan Pancasila dan berlandaskan Undang-Undang Dasar Negara Republik Indonesia Tahun 1945 serta prinsip-prinsip dasar Konvensi Hak-Hak Anak meliputi: kepentingan terbaik bagi anak."

Penjelasan dari Pasal 2 huruf b UU Perlindungan Anak, ternyata hanya meng-copy paste dari Pasal 1 Konvensi Hak Anak (KHA), yang menegaskan:

"Asas kepentingan yang terbaik bagi anak adalah bahwa dalam semua tindakan yang menyangkut anak yang dilakukan oleh pemerintah, 151.

12 Simanjuntak, 1981, Pengantar Kriminologi dan Patologi Sosial, Bandung: Tarsito, Hlm 
masyarakat, badan legislatif, dan badan yudikatif, maka kepentingan yang terbaik bagi anak harus menjadi pertimbangan utama."

Jika dihubungkan dengan dasar falsafati penjatuhan hukuman bagi anak pelaku tindak pidana dengan prinsip pengutamaan kepentingan terbaik bagi anak, maka pertimbangan psikologislah yang jauh lebih dominan. Hal ini dapat terlihat, dengan perubahan hukuman bagi anak pelaku tindak pidana secara fundamental sebagaimana yang diatur dalam UUSPPA, dibandingkan dengan KUHPidana. UUSPPA tidak memperkenankan lagi hukuman pidana penjara seumur hidup bagi anak berkonflik hukum, tetapi hanya dapat dijatuhi hukuman pidana penjara paling lama 10 tahun.

Dikatakan pertimbangan psikologis yang lebih dominan dalam prinsip pengutamaan kepentingan terbaik bagi anak, yaitu: anak dikatakan masih dalam keadaan labil, masih dalam keadaan pencarian identitas (own identity), hal itu berhubungan dengan aspek kejiwaan yang tidak memenuhi rasa keadilan jika harus dihukum seberat-beratnya.

Pertimbangan psikologis lainnya, dapat pula diambil dari batasan usia pertanggungjawaban pidana bagi anak pelaku tindak pidana, apa yang disebut usia anak sebagai masa yang rentan (tender years) masih membutuhkan pengasuhan oleh orang tuanya, masih membutuhkan sosialisasi dengan lingkungan masyarakat sehingga labelisasi perlu dihindari, pada hakikatnya terkait dengan faktor kejiwaan yang harus diperhatikan dalam prinsip pengutamaan kepentingan terbaik bagi anak.

Hal lainnya lagi, menyangkut kemampuan kognitif yang perlu diperhatikan dalam penjatuhan hukuman bagi anak berkonflik hukum, sehingga diutamakan hukuman tindakan berupa pembinaan dan pendidikan di lembaga pembinaan khusus anak, juga bagian dari faktor psikologis yang sejalan dengan pengutamaan kepentingan terbaik bagi anak.

Pengutamaan kepentingan terbaik bagi anak dalam penjatuhan hukuman juga memiliki hubungan yang erat dengan formulasi ketenetuan bagi anak pelaku tindak pidana yang berumur di bawah 14 tahun, hanya dapat dijatuhkan hukuman tindakan, demikian halnya dengan anak pelaku tindak pidana yang sudah berumur 15 tahun sd. 18 tahun, pun dapat dijatuhi hukuman pidana penjara, namun hanya dapat dilakukan sebagai syarat penghukuman relatif oleh majelis hakim tunggal pengadilan anak. 


\section{Prinsip Ultimum Remidium}

Istilah ultimum remedium pertama kali diperkenalkan oleh Menteri Kehakiman Belanda untuk menjawab pertanyaan seorang anggota parlemen bernama Meckay dalam rangka pembahasan rancangan KUHP (Kitab UndangUndang Hukum Pidana), yang mengemukakan: ${ }^{13}$

"Asas tersebut ialah bahwa yang boleh dipidana yaitu mereka yang menciptakan "onrecht" (perbuatan melawan hukum). Hal ini merupakan condito sine qua non. Kedua, ialah bahwa syarat yang harus ditambahkan ialah bahwa perbuatan melawan hukum itu menurut pengalaman tidaklah dapat ditekan dengan cara lain. Pidana itu haruslah tetap merupakan upaya yang terakhir. Pada dasarnya terhadap setiap ancaman pidana terdapat keberatan-keberatan. Setiap manusia yang berakal dapat juga memahaminya sekalipun tanpa penjelasan. Hal itu tidak berarti bahwa pemidanaan harus ditinggalkan, tetapi orang harus membuat penilaian tentang keuntungan dan kerugiannya pidana itu, dan harus menjaga jangan sampai terjadi obat yang diberikan lebih jahat dari pada penyakit."

Sejalan dengan bangunan teori di atas, pada sesungguhnya alasan penjatuhan hukum bagi pelaku tindak pidana haruslah didukung oleh asas kemanfaatan. Suatu ancaman hukum pidana setidak-tidaknya memberi manfaat baik bagi pelaku maupun tata pergaulan masyarakat. Di sinilah memunculkan teori hukuman yang tidak perlu diberikan bagi pelaku tindak pidana yang tidak memiliki kemampuan bertanggung jawab.

Adapaun uraian secara singkat tentang ultimurm remidium dikemukakan oleh van Bemellen sebagai berikut: ${ }^{14}$

"Ultimum remedium, yaitu usaha terakhir guna memperbaiki tingkah laku manusia, terutama penjahat, serta memberikan tekanan psikologis agar orang lain tidak melakukan kejahatan. Oleh karena sanksinya bersifat penderitaan istimewa, maka penerapan hukum pidana sedapat mungkin dibatasi dengan kata lain penggunaannya dilakukan jika sanksi-sanksi hukum lain tidak memadai lagi."

Dibandingkan dengan UU Pengadilan Anak dengan UUSPPA, maka UUSPPA jauh lebih maju dalam mengutamakan kepentingan terbaik bagi anak, yaitu dengan membolehkan penjatuhan hukuman pidana penjara bagi anak berkonflik hukum, hanya sebagai upaya terakhir (ultimum remidium).

13 https://restatika.wordpress.com/2010/03/08/karakteristik-hukum-pidana-dalam-konteksultimum-remedium/

${ }^{14}$ Andi Zainal Abidin. 1987, Azaz-azaz Hukum Pidana, Bandung: Alumni, Hlm. 16. 
Dalam praktik, seringkali hukuman tindakan yang dijatuhkan kepada anak berkonflik hukum menuai kecaman oleh publik. Bahkan bukan hanya publik yang kadang tidak menerima vonis pengadilan tersebut, tetapi korban kerap kali menganggap putusan hakim tidak adil. Dalam suatu kasus penganiayaan yang dilakukan oleh seorang anak geng motor terhadap seorang anggota TNI, yang pernah diputus oleh Hakim Pengadilan Negeri Makassar, mengutarakan bahwa putusan itu tidak adil, sebab hakim hanya menjatuhkan sanksi tindakan pengembalian sang anak ke orang tuanya, padahal penganiayaan yang dilakukan oleh anak itu jelas-jelas mengancam nyawa si korban (anggota TNI).

Bertitik tolak dari kasus tersebut, maka menjadi penting untuk memperkenalkan bahwa prinsip ultimum remidium diberlakukan bagi anak berkonflik hukum memiliki alasan hukum yang dapat dipertanggungjawabkan secara akademik.

Sudah pasti dalam kasus di atas, anggota TNI tersebut menghendaki anak pelaku tindak pidana agar dihukum dengan pidana penjara. Namun majelis hakim pengadilan hanya menghukumnya dengan hukuman tindakan berupa pengembalian anak kepada orang tuanya.

UUSPPA memberlakukan prinsip ultimum remidium dalam hukuman pidana penjara bagi anak berkonflik hukum, jelas-jelas harus mengacu pada ratio legis yang berdasar. Adapun ratio legis yang dimaksudkan tersebut, kembali pada dua prinsip penjatuhan hukuman yang telah dikemukakan di atas.

Prinsip pertanggungjawaban pidana yang berlaku bagi anak berkonflik hukum yaitu dalam soal atau perkara mengenai ketidakmampuan bertanggung jawab. Pun jika dijatuhkan sanksi tindakan bagi anak berkonflik hukum, sebenarnya bukan lagi dalam konteks ketidakmampuan anak pelaku tindak pidana bertanggung jawab, tetapi dari segi batasan usialah yang masih dalam masa berpikir lemah, sehingga jauh lebih adil jika diutamakan untuk pembinaan dan pendidikan bagi anak pelaku tindak pidana tersebut.

Hal yang lainnya lagi patut untuk diperhatikan, ialah prinsip pengutamaan kepentingan terbaik bagi anak juga sinkron dengan penerapan prinsip ultimum remidium bagi anak berkonflik hukum. Kendatipun penjatuhan hukuman bagi anak berkonflik hukum, pidana penjara sebagai alternatif terakhir, haruslah dipandang bahwa sanksi tindakan bagi anak berkonflik hukum setidak-tidaknya menjadi pemuas keadilan bagi korban, di samping memiliki manfaat bagi anak tersebut agar tidak lagi berbahaya atau tidak beresiko melakukan tindak pidana di masa mendatang. 
Itulah sebabnya pula, dalam UUSPPA memberlakukan upaya diversi ${ }^{15}$ bagi anak berkonflik hukum dan penerapan upaya musyawarah antara korban dengan anak berkonflik hukum berdasarkan prinsip restotarif justice. ${ }^{16}$

Pada hakikatnya cara perlakukan khusus bagi anak berkonflik hukum dalam keadaan demikian juga menjadi penyeimbang atas berlakunya prinsip ultimum remidium, sebaik-baiknya agar diupayakan anak berkonflik hukum tidak perlu di proses melalui persidangan. Akan tetapi sudah cukup dengan jalan perdamaian antara pelaku dengan korban.

Sangat logis dan memenuhi syarat sosiologis, bahwa anak berkonflik hukum hanya dapat dijatuhi pidana penjara dengan menerapkan prinsip musyawarah (restoratif justice principle), sebab anak berkonflik hukum dipandang dalam hal ketidakmampuan bertanggung jawab secara pidana baik karena pertimbangan psikologis, sosiologis, maupun pedagogis.

\section{B. Syarat Penjatuhan Hukuman Bagi Anak Berkonflik Hukum}

Dalam UUSPPA memang tidak menyebutkan adanya syarat absolut dan syarat relatif dalam penjatuhan hukuman bagi anak berkonflik hukum. Adapun syarat tersebut dimunculkan berdasarkan pendapat penulis setelah menelaah ketentuan penjatuhan hukuman bagi anak berkonflik hukum yang pada dasarnya terdapat syarat yang mengikat bagi majelis hakim pengadilan anak.

\section{Syarat Absolut}

Sebelum penulis mengemukakan apa yang dimaksud syarat absolut dalam penjatuhan hukuman bagi anak berkonflik hukum, pertama-tama dikutip terlebih dahulu secara lengkap bunyi daripada Pasal 69 ayat 2 UUSPPA yang menegaskan sebagai berikut:

"Anak yang belum berusia 14 (empat belas) tahun hanya dapat dikenai tindakan."

Jika maksud pembentuk undang-undang hendak diikuti melalui ketentuan di atas, maka yang dimaksudkan ialah anak sebagai pelaku tindak pidana yang berusia di bawah 14 tahun, hanya dikenakan sanksi tindakan. Frasa "hanya dikenai tindakan" dalam ketentuan tersebut, di situlah redaksi kalimatnya yang kiranya dapat dimaknai kalau penjatuhan hukuman bagi anak dalam batasan usia

${ }^{15}$ Marlina, 2012, Peradilan Pidana Anak di Indonesia, Bandung: Refika Aditama, Hlm. 17.

${ }^{16}$ Lilik Mulyadi, 2014, Wajah Sistem Peradilan Pidana Anak Indonesia, Bandung: Alumni, HIm. 43. 
demikian (di bawah 14 tahun) berlaku sebagai syarat absolut atau syarat otoritatif undang-undang bagi hakim pengadilan anak.

Kepada majelis hakim pengadilan anak atas pribadi jabatan yang dilekati kewenangan dalam dirinya, menjadi wajib untuk menjatuhkan sanksi tindakan saja bagi anak berkonflik hukum. Jadi, meskipun semua unsur-unsur tindak pidana yang dilakukan oleh anak terbukti di hadapan persidangan, ancaman hukuman yang dapat diterapkan, satu-satunya hanya sanksi tindakan. Tidak ada celah bagi hakim pengadilan anak untuk menjatuhkan hukuman atau sanksi pidana.

Berdasarkan Pasal 69 ayat 2 UUSPPA di atas, maka pada ketentuan tersebut dapat diperoleh pula gambaran sekaligus evaluasi perundang-undangan terkait anak dalam hal teori hukuman nir pembalasan bagi anak berkonflik hukum, bahwa terdapat alasan penghapus pidana dan alasan peringanan pidana bagi anak pelaku tindak pidana.

Alasan penghapus pidana bagi anak pelaku tindak pidana, yaitu bersandarkan pada defenisi yuridikal anak berkonflik hukum yang membatasi usia anak pelaku tindak pidana 12 sd. 18 tahun. Anak sebagai pelaku tindak pidana di bawah usia 12 tahun, berlaku alasan penghapus pidana berkualifikasi alasan pemaaf. Sedangkan anak sebagai pelaku tindak pidana dalam batas usia 12 sd 13 tahun berlaku alasan peringanan pidana, oleh karena anak sebagai pelaku tindak pidana hanya dikenakan sanksi tindakan.

Dalam tafsir literlijk atau gramatikal, Pasal 69 ayat 2 UUSPPA terdapat dua kekeliruan mendasar. Pertama, masih memungkinkan majelis hakim pengadilan anak menjatuhkan hukuman pidana bagi anak pelaku tindak pidana yang berusia di bawah 14 tahun. Hal itu disebabkan terdapat frasa "dapat" dikenai tindakan. Arti kata "dapat" dalam ketentuan tersebut, seolah-olah memberikan kemungkinan lain atau keluwesan bagi majelis hakim pengadilan untuk menjatuhkan bentuk hukuman lain, selain hukuman tindakan, setidak-tidaknya ia bisa memilih hukuman pidana, padahal bukan demikian maksud daripada pembentuk undang-undang. ${ }^{17}$

Kedua, Pasal 69 ayat 2 UUSPPA insinkronisasi dengan Pasal 1 angka 3 UUSPPA. Seolah-olah Pasal 69 ayat 2 UUSPPA memberikan kewenangan kepada hakim pengadilan untuk menjatuhkan hukuman bagi semua anak pelaku tindak pidana yang berusia di bawah 14 tahun, padahal dalam Pasal 1 angka 3 UUSPPA telah dengan tegas membatasi anak pelaku tindak pidana yang hanya dapat

17 Bandiingkan dengan pendapat Moeljatno yang menguraikan arti dari kata "dapat dihukum" dalam "Perbuatan Pidana dan Pertanggungjawaban dalam Hukum Pidana," 1959, Yogyakarta: Yayasan Badan Penerbit Gadjah Mada, Hlm. 8. 
diproses pidana, yaitu hanya yang berumur 12 tahun sd. 18 tahun. Bagi anak yang berusia di bawah 12 tahun, jangankan dapat dikenakan sanksi tindakan, berdasarkan UUSPPA pun tidak memberikan sebenarnya ruang untuk melalui proses pemeriksaan, seperti penyelidikan dan penyidikan.

Oleh karena itu, agar ketentuan daripada Pasal 69 ayat 2 UUSPPA tidak mengalami kekaburan dan harmonis dengan ketentuan atau Pasal 1 angka 3 UUSPPA (memenuhi tafsir sistematikal), maka seharusnya berbunyi: "anak pelaku tindak pidana yang berusia 12 tahun sd 13 tahun diancam dengan hukuman tindakan."

\section{Syarat Relatif}

Sama halnya dengan uraian syarat penjatuhan hukuman yang telah diuraikan di atas. Pada syarat bagian kedua ini, penulis juga terlebih dahulu mengutip ketentuan yang dapat dimaknai secara implisit sebagai syarat relatif penjatuhan hukuman bagi anak berkonflik hukum.

Adapun ketentuan yang dimaksudkan, yaitu Pasal 70 UUSPPA yang menegaskan:

"Ringannya perbuatan, keadaan pribadi anak, atau keadaan pada waktu dilakukan perbuatan atau yang terjadi kemudian dapat dijadikan dasar pertimbangan hakim untuk tidak menjatuhkan pidana atau mengenakan tindakan dengan mempertimbangkan segi keadilan dan kemanusiaan."

Berdasarkan ketentuan di atas, frasa yang dapat dimaknai sebagai syarat relatif penjatuhan hukuman bagi anak berkonflik hukum yaitu terdapat dalam kalimat "menjatuhkan pidana atau mengenakan tindakan." Pasal 70 UUSPPA merupakan ketentuan yang mengandung kalimat negatif, yang jika dipositifkan akan berbunyi:

"Ringannya perbuatan, keadaan pribadi anak, atau keadaan pada waktu dilakukan perbuatan atau yang terjadi kemudian dapat dijadikan dasar pertimbangan hakim untuk menjatuhkan pidana atau mengenakan tindakan dengan mempertimbangkan segi keadilan dan kemanusiaan."

Menyinggung kemudian dua sifat elementer tindak pidana, yaitu terdapat unsur objektif dan unsur subjektif suatu tindak pidana, maka catatan yang terdapat dalam Pasal 70 UUSPPA sebagai syarat relatif penjatuhan hukuman bagi anak berkonflik hukum, kedua unsur tidak pidana demikian terdapat dalam ketentuannya.

Ringannya perbuatan merupakan unsur subjektif yang terdapat dalam suatu tindak pidana yang harus diamati jika pelakunya adalah anak. Sementara 
pada "keadaan pribadi anak" merupakan unsur subjektif yang terdapat dalam diri anak sebagai pelaku tindak pidana.

Untuk syarat penjatuhan hukum mengenai "keadaan pada waktu dilakukan perbuatan" merupakan unsur gabungan antara unsur subjektif dan unsur objektif yang harus diperhatikan oleh hakim pengadilan anak saat mengadili kasus anak berkonflik hukum. Dikatakan sebagai unsur gabungan, karena keadaan pelaku bisa saja berasal dari luar diri anak sebagai pelaku tindak pidana, bisa pula dari dalam diri anak sebagai pelaku tindak pidana.

Jika dikembalikan pada asas penghukuman "hukumlah seorang setimpal dengan perbuatannya" berarti antara unsur tindak pidana dengan pertanggungjawaban pidana tidak terpisah, atau tidak dapat dikatakan masingmasing berdiri sendiri. Inilah yang menunjukan bahwa asas penghukuman yang dianut oleh UUSPPA berdasarkan Pasal 70 tersebut, adalah teori monisme yang menyatakan bahwa antara tindak pidana dengan pertanggungjawaban pidana satu kesatuan. Berbeda dengan pendapat Pompe $^{18}$ dan Chairil Huda ${ }^{19}$ yang menyatakan bahwa pertanggungjawaban pidana harus dipisahkan dengan unsur tindak pidananya.

Benar adanya bahwa berlaku alasan penghapus pidana bagi anak pelaku tindak pidana yang masih berusia di bawah 12 tahun, sehingga yang demikian masih memungkinkan untuk mengatakan pertanggungjawaban pidana bukanlah bagian dari unsur tindak pidana.

Begitupun dengan syarat penghukuman absolut bagi anak pelaku tindak pidana yang berusia 12 sd 13 tahun yang diancam dengan hukuman tindakan, masih memungkinkan untuk mengatakan pertanggungjawaban pidananya bukan bahagian dari unsur tindak pidana, karena ukurannya hanya sebatas pelaku yang tidak atau kurang mampu bertanggungjawab.

Akan tetapi suatu hal yang berbeda dengan syarat penjatuhan hukuman relatif, yang memungkinkan hakim pengadilan menjatuhkan hukuman antara tindakan atau pidana, antara unsur tindak pidana dengan pertanggungjawabannya satu kesatuan yang tidak dapat dipisahkan. Hal itu disebabkan, bahwa untuk melihat berat atau ringannya perbuatan adalah harus menguraikan unsur-unsur daripada tindak pidana yang dilakukan oleh anak.

${ }^{18}$ Eddy O.S. Hiareij, Op.Cit, Hlm. 161.

19 Chairil Huda, 2008, Dari Tiada Pidana Tanpa Kesalahan Menuju Kepada Tiada Pertanggungjawaban Pidana Tanpa kesalahan, Jakarta: Kencana, Hlm. 97. 


\section{PENUTUP}

Prinsip penjatuhan hukuman bagi anak pelaku tindak pidana sehingga terdapat alasan penghapus pidana berkualifikasi alasan pemaaf, juga diberlakukannya dua bentuk hukuman (tindakan dan pidana) bagi anak berkonflik hukum merupakan perwujudan lebih lanjut dari tiga prinsip penghukuman yang diakui dalam UUSPPA, yaitu prinsip pertanggungjawaban pidana, prinsip the best interes of the child dan prinsip ultimum remidium. Ketiga prinsip penghukuman tersebut juga menjadi landasan dari pembentuk UUSPPA sehingga diberlakukan dua syarat penghukuman bagi anak berkonflik hukum, yaitu syarat penghukuman absolut dan syarat penghukuman relatif.

Agar UUSPPA tidak menimbulkan reaksi penolakan dari partsipan hukum yang diatur, terutama bagi masyarakat umum. Oleh karena UUSPPA merupakan hukum yang mengatur menyangkut kepentingan umum, maka sebaiknya UUSPPA dilengkapi penjelasan yang lebih gampang dipahami terkait alasan atau ratio legis yang menjadi dasar pembeda hukumannya antara anak berkonflik hukum dengan orang dewasa yang melakukan tindak pidana. Selain itu, batasan usia bagi anak berkonflik hukum yang diancam dengan hukuman tindakan, harus memperjelas batasan usia anak antara 12 sd 13 tahun, sehingga tidak tumpang tindih dengan prinsip pertanggungjawaban pidana terhadap anak pelaku tindak pidana sebagai pengecualian oleh UUSPPA yang tidak dapat diproses secara pidana. 


\section{DAFTAR PUSTAKA}

Abidin, Andi Zainal. (1987). Azaz-azaz Hukum Pidana. Bandung: Alumni.

Ali, Achmad. (2002). Menguak Tabir Hukum. Jakarta: Toko Gunung Agung.

Conztanzo, Mark. (2006). Aplikasi Psikologi dalam Sistem Hukum, Jakarta: Pustaka Pelajar.

Fletcher, George P. (1998). Basic Concepts of Criminal Law. Cambridge: University Press.

Hanafi. (1976). Asas-asas Hukum Pidana Islam, Jakarta: Bulan Bintang.

Hart. (2013). Konsep Hukum. Bandung: Nusa Media.

Hiariej, Eddy O.S. (2016). Prinsip-prinsip Hukum Pidana. Yogyakarta: Cahaya Atma Pustaka.

Hidayat, Bunadi. (2014). Pemidanaan Anak di Bawah Umur. Bandung: Alumni.

Huda, Chairil. (2008). Dari Tiada Pidana Tanpa Kesalahan Menuju Kepada Tiada Pertanggungjawaban Pidana Tanpa kesalahan. Jakarta: Kencana.

Marlina. (2012). Peradilan Pidana Anak di Indonesia, Bandung: Refika Aditama.

Moeljatno. (1959). Perbuatan Pidana dan Pertanggungjawaban dalam Hukum Pidana. Yogyakarta: Yayasan Badan Penerbit Gadjah Mada.

Mulyadi, Lilik. (2014). Wajah Sistem Peradilan Pidana Anak Indonesia, Bandung: Alumni.

Simanjuntak. (1981). Pengantar Kriminologi dan Patologi Sosial. Bandung: Tarsito.

Utrecht, E. (1965). Hukum Pidana II, Djakarta: Pustaka Tinta Mas.

van Hammel, G. A. (1913). Inleiding Tot de Studie Van Het Nederlansche strafrecht. Derde Druk: De Erven F. Bohn Haarlen \& Gebr. Belinfante'sGravenhage. 